\title{
АДМІНІСТРАТИВНО-ПРАВОВЕ ЗАБЕЗПЕЧЕННЯ ДІЯЛЬНОСТІ ОРГАНІВ НАЦІОНАЛЬНОЇ ПОЛІЦІЇ УКРАЇНИ З УДОСКОНАЛЕННЯ РЕАЛІЗАЦІї ПРАВОЗАХИСНОЇ ФУНКЦІЇ ДЕРЖАВИ
}

Грохольський В. Л.

Стаття присвячена висвітленню актуальних питань адміністративно-правового забезпечення діяльності Національної поліції України з реалізації правозахисної функціі держави. Визначається, що від якості адміністративно-правового забезпечення діяльності Національної поліціі України залежить і якість виконання правозахисної функції держави.

У статті основна увага приділена визначенню шляхів удосконалення адміністративно-правового забезпечення управлінської діяльності органів Національної поліції України, які поділено на три напрямки: вдосконалення правотворчої (нормотворчої), правозастосовної і правоохоронної діяльності.

Ключові слова: адміністративно-правове забезпечення, Національна полічія, правотворча (нормотворча), правозастосовна і правоохоронна діяльність.

Статья посвящена освещению актуальных вопросов административно-правового обеспечения деятельности Национальной полиции Украины по реализации правозащитной функции государства. Определяется, что от качества административно-правового обеспечения деятельности Национальной полиции Украины зависит и качество выполнения правозащитной функции государства.

B cтатье основное внимание уделено определению путей усовершенствования административно-правового обеспечения управленческой деятельности органов Национальной полиции Украины, которые разделены на три направления: усовершенствование правотворческой (нормотворческой), правоприменительной и правоохранительной деятельности.

Ключевые слова: административно-правовое обеспечение, Национальная полиция, правотворческая (нормотворческая), правоприменительная и правоохранительная деятельность.

The article is devoted to covering topical issues of administrative and legal support for the activities of the National Police of Ukraine in the implementation of the human rights function of the state. It is determined that, depending on the quality of administrative and legal support for the activities of the National Police of Ukraine, the quality of the human rights function of the state depends. Despite the reforming of the National Police System of Ukraine, the study and use of foreign experience, the activities of the National Police are still ineffective and, in many respects, the existing problems have not been resolved.

The article focuses on identifying ways to improve the administrative and legal support of the administrative activities of the bodies of the National Police of Ukraine, which are divided into three areas: improvement of law-making (rule-making), law using and law enforcement activities.

It is determined that as the main components of administrative and legal support, these categories act as legal ways

Грохольський В. Л., 2019 of external expression and internal organization of administrative and management activity. They are aimed at organizing the implementation of specific subjects of their rights and responsibilities. However, each of them has a specific content and a special legal formulation of the respective actions.

Attention is drawn to the fact that difficulties in the administrative and legal support of the activities of the National Police often arise not because of lack of mandatory rules of conduct, but because of their disorder, insecurity, contradiction and lack of resources.

It is noted that in many legal acts there is no comprehensive approach to solving the issues of police activity, they duplicate each other and do not comply with the rules of legal technique. They are distinguished by norms-declarations and are lagging behind the real processes taking place in society.

It is emphasized that law enforcement in management activities is somewhat different from the generally accepted understanding of law enforcement as one of the elements of the mechanism of legal regulation, and the differences were shown

Key words: administrative and legal support, National police, law-making (law norms making), law using and law enforcement activities.

Постановка проблеми. Національну поліцію України з упевненістю можна віднести до одного з основних суб'єктів реалізації правозахисної функції держави. Залежно від адміністративно-правового забезпечення іiі діяльності залежить і якість правозахисної функції держави. Сьогодні, на жаль, реформована система Національної поліції України, незважаючи на вивчення і посилання на зарубіжний досвід, все ще залишається малоефективною, і багато в чому наявні проблеми не вирішені. Система Національної поліції України продовжує залишатися такою, що не відповідає міжнародним стандартам захисту прав людини, відмічається каральною спрямованістю, корупційними зв'язками, залежною від владних осіб, громіздким управлінським апаратом, низьким рівнем адміністративно-правового і кадрового забезпеченням та ін. Ці та інші фактори суттєво впливають на рівень довіри населення до поліції та його наміри щодо співпраці з поліцією. Тому важливою передумовою ефективної діяльності органів Національної поліції України з реалізації правозахисної функції держави $\epsilon$, перш за все, вдосконалення адміністративно-правового забезпечення їхньої діяльності на управлінському рівні.

Стан дослідження. Окремим питанням дослідження адміністративно-правового забезпечення діяльності органів Національної поліції України присвятили свої наукові праці О.М. Бандурка, М.Г. Вербенський, В.Л. Грохольський, А.В. Денисова, О.С. Доценко, Д.П. Калаянов, М.В. Корнієнко, М.Н Курко, В.І. Литвиненко, Т.М. Міщенко, О.Ю. Шостко, Х.П. Ярмакі та багато інших. Водночас сьогодні рівень адміністративно-пра- 
вового забезпечення управлінської діяльності органів Національної поліції України з удосконалення реалізації правозахисної функції держави залишається малоефективним і в багатьох питаннях чітко не визначеним.

Метою цієї статті $\epsilon$ визначення шляхів удосконалення адміністративно-правового забезпечення управлінської діяльності органів Національної поліції України з реалізації правозахисної функції держави.

Виклад основного матеріалу. У залежності від змісту дій, що виконуються, представляється доцільним виділити три напрями вдосконалення адміністративно-правового забезпечення управлінської діяльності органів Національної поліції України з реалізації правозахисної функції держави: вдосконалення правотворчої (нормотворчої), правозастосовної і правоохоронної діяльності. Будучи основними складовими частинами адміністративно-правового забезпечення управлінської діяльності органів Національної поліції України, ці категорії виступають як юридичні способи зовнішнього вираження i внутрішньої організації адміністративно-управлінської діяльності. Вони спрямовані на організацію виконання конкретними суб'єктами своїх прав і обов' язків. Разом із тим кожна з них відрізняється специфічним змістом і особливим юридичним оформленням відповідних дій.

У процесі правотворчості (нормотворчості) розробляються і приймаються (чи скасовуються) нормативно-правові акти як типові правила поведінки. Дана діяльність завершується прийняттям нормативно-правового акта. У процесі їх застосування видаються акти правозастосування, які містять індивідуально-конкретні правові розпорядження, що встановлюють (закріплюють, змінюють чи припиняють) на основі правових норм конкретні суб'єктивні права й обов'язки персонально зазначених осіб [1, с. 148, 181].

Правотворчість (нормотворчість) у системі Національної поліції України складається з нормативно-правових актів МВС України та Національної поліції України. За допомогою їх правотворчості (нормотворчості) робиться нормативний, організуючий вплив на вирішення типових суспільних відносин у діяльності органів, підрозділів Національної поліції, що дає можливість досягти єдиного, однотипного порядку діяльності поліції у вирішенні типових суспільних відносин, підкорити поводження людей загальним і однаковим правилам, продиктованим вимогами сьогодення.

Правозастосування - індивідуальні нормативно-правові акти, за допомогою яких здійснюється вплив на конкретно визначених учасників у конкретних суспільних відносинах. Це дозволяє вирішити життєві проблеми з урахуванням особливостей даної ситуації, персональних якостей осіб, характеру відносин тощо.

Правоохоронна виражається в контролі за дотриманням нормативно-правових актів, у створенні умов їхнього функціонування, що пов'язано із правомірним поводженням осіб і застосуванням юридичного впливу (санкцій) до осіб, які не дотримуються приписів нормативно-правових актів та скоїли правопорушення.

Слід відмітити, що взаємозалежність правотворчості (нормотворчості) і правозастосування в системі діяльності органів Національної поліції має складний характер. По-перше, нормативно-правові акти всіх суб'єктів виконавчої влади видаються з метою виконання законів. Це значить, що здійснювана MBC України та Наці- ональною поліцією України, як органами державної виконавчої влади і безпосереднім суб'єктом управління органами Національної поліції, нормотворчість служить цілям правозастосування (виконання правових норм вищого рівня), а прийняті ними норми містять у своєму змісті двояке юридичне навантаження: правотворче і правозастосовне. По-друге, правотворчий (нормотворчий) процес, як правило, починається i закінчується прийняттям акта правозастосування. По-третє, акти правозастосування у вигляді наказів часто самі містять правові норми, спрямовані на організацію виконання затверджуваних актів. По-четверте, в деяких випадках одночасно готуються й одним наказом затверджуються нормативні і правозастосовні акти, спрямовані на досягнення єдиної мети. По-п'яте, нормативно-правові акти, видані у вигляді наказів, досить часто носять змішаний характер, містять одночасно і норми, і індивідуальні розпорядження. Їх прийняття переслідує нормотворчі і правозастосовні цілі, що пов'язано зі складністю адміністративно-управлінських відносин, багатоплановістю адміністративно-правового забезпечення діяльності Національної поліції і недоцільністю з одного питання видавати декілька нормативно-правових актів. Тому можна сказати, що відомча нормотворчість i правозастосування являють собою правові форми адміністративно-управлінської діяльності. А управлінські рішення, оформлені відповідним чином, $\epsilon$ нормативно-правовими актами нормативного або правозастосовного (індивідуального) характеру.

Поряд зі змістовним аспектом правової форми управління нормотворчість містить у собі процедурний аспект, тобто вона може розглядатися як процес підготовки i прийняття нових управлінських рішень, перегляду і скасування рішень, які втратили практичне чи юридичне значення. Нормотворчому процесу притаманна певна визначеність послідовності стадій (етапів), які $\epsilon$ взаємозалежними та об'єднуються у єдиний процес, який забезпечує прийняття та видання нормативноправового акта.

До основних стадій нормотворчого процесу можна віднести: визначення (з'ясування) необхідності прийняття нормативно-правового акта; прийняття рішення про розроблення його проекту; визначення виконавців розроблення проекту нормативно-правового акта, за необхідності створюється робоча група в т.ч. і міжвідомча; збір, аналіз та оцінка зібраної інформації, підготовка проекту нормативно-правового акта, підготовка пояснювальної записки, в необхідних випадках - фінансово-економічне обґрунтування i т.п.; узгодження проекту зі службовими особами відповідних органів, підрозділів, керівництвом інших органів державної влади та іншими зацікавленими службовими особами; ухвалення проекту рішення керівником (затвердження, відхилення, вказівка про доопрацювання); погодження, реєстрація в органах юстиції у випадках, визначених чинним законодавством; видання нормативно-правового акта. Перераховані стадії, у свою чергу, складаються з певних послідовних дій, докладно охарактеризованих у ряді робіт представників відомчої науки [2; $3 ; 4]$.

Варто відзначити, що труднощі в адміністративно-правовому забезпеченні діяльності органів Національної поліції часто виникають не у зв'язку з відсутністю обов'язкових правил поведінки, а у зв'язку з їх невпорядкованістю, неконкретністю, суперечливістю 
i ресурсною незабезпеченістю. У багатьох нормативно-правових актах відсутній комплексний підхід до вирішення питань діяльності поліції, окремі нормативно-правові акти дублюють один одного, не відповідають правилам юридичної техніки, виділяються нормами-деклараціями і відстають від реальних процесів, що відбуваються у суспільстві.

Прийняті МВС України та Національною поліцією України нормативно-правові акти в сукупності із законами, указами Президента України, постановами і розпорядженнями Кабінету Міністрів України утворюють нормативно-правову основу діяльності Національної поліції. Однак, як уже відмічалося вище, нормативно-правова база сама по собі не в усіх випадках забезпечує реалізацію правових норм. У випадку неспроможності об'єкта управління самостійно здійснювати реалізацію нормативно-правових актів, коли юридичні обов'язки не виконуються добровільно, а також коли згадані форми реалізації ними своїх прав і обов'язків недостатні для повної реалізації правових норм, у правореалізуючу діяльність об'єктів управління втручаються суб'єкти управління i, використовуючи свої владні повноваження, забезпечують реалізацію нормативно-правових актів відносно конкретних осіб і конкретної ситуації, здійснюючи тим самим правозастосовну діяльність.

Слід наголосити, що правозастосування в управлінській діяльності відрізняється від загальноприйнятого розуміння правозастосування як одного з елементів механізму правового регулювання. I в першому, i у другому випадках зміст правозастосування буде виражатися у виданні на підставі норм права в межах повноважень суб'єкта, що застосовує норму права, індивідуальних правових актів. Однак у сфері управління правозастосування спрямоване на об'єкт управління з метою надання допомоги у використанні об'єктом управління своїх прав і виконання обов'язків. В окремих випадках правозастосування в управлінській діяльності спрямоване на припинення неправомірної поведінки об'єкта управління та спонукання його до правомірної поведінки чи ефективної діяльності.

Таким чином, можна сказати, що правозастосування у сфері адміністративно-управлінської діяльності органів Національної поліції спрямоване на: а) практичну організацію адміністративно-управлінської діяльності; б) здійснення адміністративно-розпорядчого впливу суб'єкта управління на об'єкт управління за допомогою прийняття актів індивідуального характеру; в) організацію виконання об'єктами управління прийнятих рішень. Правозастосування забезпечує організованість в управлінській діяльності і додає йому офіційний характер.

Однією з форм правозастосування у сфері адміністративно-управлінської діяльності в органах Національної поліції виступає процес організації виконання нормативно-правових актів. Його можна поділити на два види. У першому випадку - під час прийняття на рівні МВС України та Національної поліції України нормативно-правового акта у вигляді наказу, розпорядження, вказівки, інструкції, настанови, положення, правил тощо. Як правило, водночас розробляються і організаційні заходи, пов'язані з його реалізацією, що знаходить своє відображення в наказі, яким затверджується даний нормативний акт. У другому випадку акт правозастосування видається для організації і забезпечення своєчасного і точного виконання (дотримання) прийнятих законів України, виданих указів Президента України, прийнятих постанов, розпоряджень Кабінету Міністрів України тощо. Необхідно відзначити, що порядок прийняття організаційних рішень, спрямованих на виконання правових актів в системі МВС України та Національної поліції України, нормативно не урегульований. Тому стає незрозумілим, в яких випадках потрібно видання правозастосовного акта і якого змісту, чи потрібно щоразу приймати нове управлінське рішення, що, як правило, містить стандартний перелік заходів. Відсутність нормативного регулювання даної сфери управлінської діяльності може призводити до організаційних упущень: в одних випадках можлива заорганізованість управлінського процесу, а в інших відсутність необхідного управлінського впливу.

Правозастосовні акти, як і нормативні, мають потребу у визначеній уніфікації, стандартизації, що не тільки полегшує їх складання і використання, але й сприяє впорядкуванню правового регулювання. Уніфікація досягається шляхом установлення вимог до правозастосовних актів у відповідних нормативно-правових актах, затвердженням зразків. Слід зазначити, що наказом МВС України від 27.07.2012 р. № 650 затверджена Інструкція з оформлення документів у системі MBC України [5], які видаються керівниками органів Національної поліції у правозастосовній діяльності.

Включення у правозастосовний акт правових норм фактично перетворює його в нормативний акт тимчасової властивості. Особливо часто можна зустріти нормативні вказівки у планах роботи Національної поліції України та Головних Управлінь Національної поліції. Такі акти ускладнюють сприйняття норм як розпоряджень. Як правило, включені у план норми лише дублюють розпорядження нормативно-правових актів, указують на формальний підхід до його підготовки. У такому випадку втрачається необхідність прийняття правозастосовного акта, що покликаний не дублювати нормативно закріплені завдання і функції, а конкретизувати їх стосовно до оперативної обстановки, що складається, часу і суб'єктів їх реалізації, визначати пріоритетність дій, координувати індивідуальні зусилля різних підрозділів і органів Національної поліції.

Правоохоронна діяльність, як один із напрямків правового забезпечення управління в органах Національної поліції, являє собою діяльність із підтримки встановленого порядку, здійснювану вищестоящими управлінськими ланками стосовно органів, підрозділів нижчого підпорядкування.

Під час встановлення мір відповідальності за невиконання правових розпоряджень варто пам'ятати, що управлінські відносини настільки складні, а ситуації можуть бути такими різноманітними, що в багатьох випадках правова норма не може містити і передбачати однозначного рішення, закріпивши визначене поводження як правомірне, а відхилення від нього - як правопорушення.

У силу зазначеної обставини основна особливість у сфері адміністративно-правового забезпечення діяльності органів Національної поліції полягає не в розробленні розгалуженої системи покарань, що чуйно реагує на всілякі відхилення, порушення, помилки під час виконання наказів, розпоряджень, вказівок, посадових обов'язків і т. п., а у створенні такого механізму відповідальності, що забезпечував би належне виконання 
обов'язків. Головним у цьому механізмі повинне бути не тільки примусове виконання невиконаних обов'язків, що має місце сьогодні, а також моральна, матеріальна та кар'єрного зростання зацікавленість.

Проведений аналіз сутнісних взаємозв'язків правотворчості, правозастосування і правоохорони свідчить про необхідність їхнього урівноваженого розвитку. Незбалансованість цих елементів негативно позначається на функціонуванні системи адміністративно-правового забезпечення діяльності Національної поліції в цілому. Так, наприклад, у системі МВС України та Національної поліції України можна відзначити підвищену активність у правотворчій сфері: приймаються нові і змінюються чинні нормативно-правові акти, змінюється техніка правотворчості. Але, на жаль, поки що відсутня система упорядкування цих актів. Дана діяльність $€$ предметом наукових досліджень. На відміну від правотворчої сфери, правозастосуванню і правоохоронні приділяється значно менше уваги: процес правозастосування нормативно не врегульований, відсутні дослідження ефективності правових норм, не діє належним чином механізм зворотного зв'язку між суб'єктами правотворчості і виконавцями правових розпоряджень, правотворчі помилки вчасно не виправляються, невиконання правових норм у багатьох випадках не спричиняє юридичну відповідальність, причини правового нігілізму не вивчаються.

Представляється доцільним у діяльності Національної поліції України наказом МВС України розділити сфери правозастосовної діяльності між суб'єктами управління і визначити, які питання варто вирішувати на рівні $M B C$ України, які - на рівні центрального органу управління Національною поліцією України, Головних Управлінь Національної поліції, міських, районних, міжрайонних органів Національної поліції одноосібно, а які -колегіально (на засіданнях колегій, оперативних нарадах, комісій, рад). Із метою виключення фактів видання нормативно-правових актів не уповноваженими на те суб' $є$ ктами управління слід установити заборону на включення нормативних розпоряджень у правозастосовні акти (плани, програми, дисциплінарні накази і т. ін.).

\section{Актуальні проблеми історико-правової та міжнародно-правової науки}

Висновок. Таким чином, можна сказати, що вдосконалення адміністративно-правового забезпечення діяльності органів Національної поліції як одного з основних суб'єктів реалізації правозахисної функції держави повинно бути нерозривно пов'язане з визнанням верховенства права в системі нормативних актів і всіх актів реалізації права із забезпеченням єдиної спрямованості правотворчості, правозастосування і правоохорони; з необхідністю вибору строго в межах закону найбільш оптимальних, що відповідають цілям і завданнями суспільства варіантів здійснення правотворчої, правозастосовної i правоохоронної діяльності; з неприпустимістю протиставлення законності i доцільності i, нарешті, з досягненням оптимального ступеня правової регламентації діяльності поліції, фактичного виконання правових розпоряджень в усіх видах діяльності і невідворотністю відповідальності за будьяке їх порушення.

\section{Література}

1. Хропатюк В.Н. Теория государства и права. Хрестоматия : учебное пособие. Москва, 1998. 944 с.

2. Бандурка О.М. Основи управління в органах внутрішніх справ України: теорія, досвід, шляхи удосконалення. Харків : Основа, 1996. 398 с.

3. Грохольський В.Л. Організаційно-правові засади управління спеціальними підрозділами МВС України по боротьбі з організованою злочинністю: монографія. Харків : Вид-во Нац. ун-ту внутр. справ, 2003. 312 с.

4. Плішкін В.М. Теорія управління органами внутрішніх справ : підручник. Київ : Національна академія внутрішніх справ України, 1999. 702 с.

5. Інструкція з оформлення документів у системі МВC України : затв. наказом МВС України від 27.07.2012 р. № 650 .

Грохольський В. Л., доктор юридичних наук, професор, професор кафедри кібербезпеки та інформаційного забезпечення Одеського державного університету внутрішніх справ 